\title{
Correlation among mutans streptococci counts, dental caries, and IgA to Streptococcus mutans in saliva
}

\section{Correlação entre contagens de estreptococos do grupo mutans, cárie dentária e IgA anti-Streptococcus mutans na saliva}

\author{
Cristiane Yumi Koga-Ito* \\ Clélia Aparecida de Paiva Martins** \\ Ivan Balducci*** \\ Antonio Olavo Cardoso Jorge ${ }^{* * * *}$
}

\begin{abstract}
Two-hundred and forty individuals were studied, divided into five groups as follows: caries-free children, children with caries, children with rampant caries, young adults with and without caries. Whole stimulated saliva was collected and all individuals were investigated for DMFT/dmft according to the WHO criteria and the simplified oral hygiene index (OHI-S). Quantitative analysis of the total aerobic flora and mutans streptococci in saliva was performed. Also, the level of salivary anti-S. mutans IgA was determined by ELISA. Children with rampant caries showed the highest OHI-S value. The highest total counts of microorganisms were found in the group of children with caries. No statistically significant differences were observed for salivary flow, OHI-S and microorganism counts between the groups of young adults. No correlation between mutans streptococci counts and anti-Streptococcus mutans IgA levels was observed in the studied groups. A correlation between increased anti-Streptococcus mutans IgA levels and caries-free status was observed among young adults but not among children.
\end{abstract}

DESCRIPTORS: Streptococcus mutans; IgA; Saliva.

\begin{abstract}
RESUMO: Duzentos e quarenta indivíduos divididos em cinco grupos foram estudados: crianças livres de cáries, crianças com cáries, crianças com cáries rampantes, adultos jovens com e sem cáries. Saliva total estimulada foi coletada, e todos os indivíduos foram investigados para CPO-D/ceo-d seguindo-se os critérios da OMS e o índice de higiene oral simplificado (IHOS). Foi também realizada a quantificação da microbiota aeróbica total e de estreptococos do grupo mutans na saliva. Além disso, o nivel de IgA anti-S. mutans foi determinado por ELISA. Crianças com cárie rampante apresentaram maior valor de IHOS. A contagem total de microrganismos mais elevada foi encontrada no grupo de crianças com cárie. Nenhuma diferença estatisticamente significativa foi observada em relação a fluxo salivar, IHOS e contagens de microrganismos entre os grupos de adultos jovens. Nenhuma correlação entre contagem de estreptococos do grupo mutans e niveis de IgA anti-Streptococcus mutans foi observada em nenhum dos grupos estudados. Foi encontrada uma correlação entre niveis mais altos de IgA anti-S. mutans e ausência de cáries entre os adultos jovens, mas não entre as crianças.
\end{abstract}

DESCRITORES: Streptococcus mutans; IgA; Saliva.

\section{INTRODUCTION}

The infectious nature of dental caries assumes the hypothesis that some form of host immunity can regulate caries activity ${ }^{2}$. Salivary IgA seems to be directly involved in the immunity to dental caries. This immunoglobulin presumably prevents the adherence of cariogenic microorganisms to hard surfaces $^{7}$, and may also inhibit the activity of glucosyltransferases ${ }^{10}$.
Previous investigations have reported contradictory results in relation to the immunity to dental caries. Some authors reported higher levels of salivary IgA in caries-resistant individuals in relation to caries-susceptible ones, suggesting an effective protective function ${ }^{4,12,20}$. Legler et al. ${ }^{15}$ (1981) observed higher caries incidence in patients with IgA deficiency. On the other hand, other authors did

* PhD, Assistant Professor, Discipline of Microbiology and Immunology, Department of Biosciences and Oral Diagnosis; ** MSc in Oral Pathology; ${ }^{* * *}$ MSc, Professor, Discipline of Biostatistics, Department of Social and Pediatric Dentistry - School of Dentistry of São José dos Campos, São Paulo State University.

**** Head Professor, Discipline of Microbiology and Immunology, Department of Dentistry, University of Taubaté. 
Koga-Ito CY, Martins CAP, Balducci I, Jorge AOC. Correlation among mutans streptococci counts, dental caries, and IgA to Streptococcus mutans in saliva. Braz Oral Res 2004;18(4):350-5.

not observe any correlation between caries activity and salivary IgA levels ${ }^{19,22}$. The influence of IgA antibodies on the experimental implantation and elimination of $S$. mutans has also been reported in the related literature ${ }^{14,18}$.

Age-dependent variations in IgA concentrations were reported by Tappuni, Challacombe ${ }^{21}$ (1995). These authors observed lower concentrations of IgA in predentate children in relation to dentate ones, and the highest values of IgA among adults. Challacombe et al. ${ }^{5}$ (1995) reported lower levels of IgA among the elderly. On the other hand, Närhi et al. ${ }^{16}(1994)$ did not observe any alterations related to age. Based on the lack of conclusive information on dental caries immunity, the aim of this study was to analyze the correlation among mutans streptococci counts, dental caries experience, and levels of IgA anti-Streptococcus mutans in saliva.

\section{MATERIALS AND METHODS}

A total of 240 individuals were analyzed, divided into five groups as follows:

- Children groups: i) caries-free children: 30 individuals, 13 females and 17 males, 312 years of age (mean \pm standard deviation $=5.53 \pm 1.31$ years) with $\mathrm{dmft} / \mathrm{DMFT}=0$; ii) children with caries: 50 individuals, 28 females and 22 males, 3-12 years of age $(6.42 \pm 1.86)$ with dmft/DMFT $>0$ and without active lesions; iii) children with rampant caries: 30 patients, 19 females and 11 males, 3 -12 years of age $(5.70 \pm 1.80)$ with 10 or more active and non-treated dental caries lesions. The children included in the study were students from schools localized in the city of São José dos Campos, SP, Brazil.

- Young adult groups: i) caries-free young adults: 30 individuals, 18 females and 12 males, $18-25$ years of age $(18.93 \pm 2.12)$ with $\mathrm{DMFT}=0$; ii) young adults with dental caries: 100 individuals, 58 females and 42 males, 1825 years of age $(20.37 \pm 1.89)$, with DMFT $>0$ and without active lesions. The young adults included in the study were students of the School of Dentistry of São José dos Campos, São Paulo State University (UNESP).

This study was submitted to and approved by the São José dos Campos School of Dentistry Bioethics Committee. All the volunteers or the responsible person (in case of children) were in- formed about the aim of the study and authorized the clinical examination and saliva sample collection. A single examiner examined all the patients. Dental health data were collected through clinical examination, recording dental caries prevalence by means of the DMFT/dmft index as defined by the $\mathrm{WHO}^{24}$ (1977). Oral hygiene was recorded according to the simplified oral hygiene index (OHI-S) as defined by Greene, Vermillion ${ }^{9}$ (1964).

\section{Saliva collection and salivary flow determination (SF)}

For saliva sample collection, sugarless gum (Epoxiglass Indústria e Comércio de Produtos Químicos Ltda., Diadema, Brazil) was given to the patients aiming at the stimulation of salivary flow. Whole saliva was collected in sterile cups (Laborglass, São Paulo, Brazil), discharging the first portion, and the salivary flow determination was performed according to Krasse ${ }^{13}$ (1986).

\section{Quantitation of total aerobic microbiota}

The total aerobic microbiota of mixed saliva was studied by plating duplicate samples of saliva dilutions $\left(10^{-1}, 10^{-2}, 10^{-3}\right.$ and $\left.10^{-4}\right)$ on blood agar plates (Tryptic soy agar, Difco, Detroit, USA; $5 \%$ rabbit blood) and incubating for 2 days at $37^{\circ} \mathrm{C}$.

\section{Mutans streptococci counts and identification}

In a maximum period of 3 hours after sampling, saliva samples were diluted to $10^{-1}, 10^{-2}$ and $10^{-3}$ and mutans streptococci counts were performed. For this purpose, the dilutions of saliva were plated on mitis salivarius (Difco, Detroit, USA) bacitracin sucrose agar for $72 \mathrm{~h}$ in candle jars (Nigro, São Paulo, Brazil) at $37^{\circ} \mathrm{C}$. After this period, the colonies of mutans streptococci were counted. Five colonies from each patient were stored for Streptococcus species identification, which was performed according to Hardie ${ }^{11}$ (1986).

\section{Anti-Streptococcus mutans antibody analysis}

Saliva samples containing $5.0 \mathrm{mM}$ phenylmethylsulfonyl fluoride (PMSF) (Sigma, St. Louis, USA) and $0.002 \%$ sodium azide (Merck, Darmstadt, Germany) were stored at $-20^{\circ} \mathrm{C}$ until antibody analysis. S. mutans ATCC 35688 grown in tryptic soy broth (Difco, Detroit, USA) for $72 \mathrm{~h}$ at $37^{\circ} \mathrm{C}$ in candle jars was used as source of antigen. The cells killed with thimerosal (Merthiolate ${ }^{\mathrm{TM}}$, 
Koga-Ito CY, Martins CAP, Balducci I, Jorge AOC. Correlation among mutans streptococci counts, dental caries, and IgA to Streptococcus mutans in saliva. Braz Oral Res 2004;18(4):350-5.

Sigma, St. Louis, USA) (0.2 g/1) were harvested by centrifugation and washed three times with $125 \mathrm{mM}$ Tris-HCl (Gibco BRL, New York, USA), $\mathrm{pH}$ 6.8. The antigens were extracted from cells by boiling in $125 \mathrm{mM}$ Tris-HCl, pH 6.8, $20 \mathrm{mM} 2-$ mercapethanol (Sigma, St. Louis, USA), $6 \mathrm{M}$ urea (Merck, Darmstadt, Germany) for 5 min. Then, the boiled product was centrifuged at $10,000 \mathrm{~g}$ for $30 \mathrm{~min}$ at $4^{\circ} \mathrm{C}$ and the supernatant was dialyzed against three changes of 3 liters of distilled water and lyophilized. Antigen preparation was stored at $-20^{\circ} \mathrm{C}$ until use. Protein amount was determined by the method of Bradford ${ }^{3}$ (1976).

\section{ELISA}

Antibody levels were measured by solid-phase ELISA, performed in 96-well, flat-bottomed plates (number 3590, Costar, Cambridge, MA, USA). All plates were coated with $50 \mu 1$ of crude antigen solution $(100 \mu \mathrm{g} / \mathrm{ml})$ dissolved in $0.1 \mathrm{M}$ carbonate buffer (Merck, Darmstadt, Germany) (pH 9.6), incubated for $2 \mathrm{~h}$ at $37^{\circ} \mathrm{C}$ and overnight at $4^{\circ} \mathrm{C}$. The wells were blocked with $0.5 \%$ gelatin $(\mathrm{G})$ (Merck, Darmstadt, Germany) in phosphate buffered saline (PBS) (Sigma, St. Louis, USA) for $1 \mathrm{~h}$. Then, the plates were washed five times with $0.5 \%$ Tween 20 PBS (T-PBS) (Merck, Darmstadt, Germany) and incubated with $50 \mu 1$ of saliva sample diluted in T-PBS-G at $1: 8$ for 2 hours at $37^{\circ} \mathrm{C}$. After an additional wash step with T-PBS, the wells were filled with goat anti-human immunoglobulin A peroxidase-labelled (Sigma, St. Louis, USA) and incubated for 1 hour at $37^{\circ} \mathrm{C}$. Finally, $100 \mu \mathrm{l} /$ well of o-phenylenediamine (Merck, Darmstadt, Germany) in $0.1 \mathrm{M}$ citrate buffer (Merck, Darmstadt, Germany) ( $\mathrm{pH}$ 5.5) were added at room temperature until a yellow color developed. The reaction was stopped with $2.5 \mathrm{M} \mathrm{H}_{2} \mathrm{SO}_{4}$ (Merck, Darmstadt, Germany) and the color was measured at $490 \mathrm{~nm}$ with a model 3550 reader (Bio Rad Laboratories, Hercules, California). The data were expressed as values of optical density (OD), obtained by the mean of two readings.

\section{Statistical analysis}

In our study, descriptive statistic data were presented as means and standard deviation values. Dependent variables were OHI-S, SF, mutans streptococci counts and IgA anti-Streptococcus mutans. The independent variable was dental caries (caries free, with caries and with rampant caries). Statistical significance of differences among groups was tested by means of one-way ANOVA (parametric and non-parametric approaches). Post hoc multiple comparisons were performed according to Tukey's and Dunn's (5\%) tests. Statistical significance was defined at $\alpha=5 \%$. The correlation between anti-S. mutans IgA levels and mutans streptococci salivary concentrations was tested by Spearman's rank order correlation. Statistical analysis was performed using the software Statistix for Windows (2000, version 7.0, analytical software, Tallahasse, USA) and Statistica for Windows (version 5.0, 1995, StatSoft Inc., Oklahoma, USA).

\section{RESULTS}

Considering the salivary flow, no differences could be observed among the children groups (ANOVA, $\mathrm{F}_{2 ; 107}=0.25, \mathrm{p}=0.781$ ). For OHI-S, children with rampant caries showed the highest value and significant differences were observed in relation to the other groups (ANOVA, $\mathrm{F}_{2 ; 107}=11.52$, $\mathrm{p}=0.001$ and Tukey's test 5\%).

Statistically significant differences were observed for the total aerobic microbiota among the children groups (ANOVA $\mathrm{F}_{2 ; 107}=9.53 ; \mathrm{p}=0.001$ and Tukey's test). The multiple comparison test (Tukey's test 5\%) showed that children with caries presented higher counts in relation to the cariesfree group. Children with rampant caries presented an intermediary value and significant differences were not found in relation to the other studied groups.

The group of children with caries also presented the highest salivary concentration of mutans streptococci with a significant difference in relation to the controls (ANOVA $\mathrm{F}_{2 ; 107}=3.38 ; \mathrm{p}=0.038$ and Tukey's test 5\%).

Considering the young adult groups, the Mann-Whitney statistical test detected no significant differences for salivary flow $(p=0.951)$ and OHI-S values $(p=0.514)$. Also, for total aerobic microbiota $(\mathrm{p}=0.918)$ and mutans streptococci $(p=0.406)$ salivary concentrations, no statistically significant differences could be observed between median values.

Graph 1 shows the box plot for the optical density (OD) values obtained for immunoglobulins against Streptococcus mutans. Statistically significant differences were detected by the MannWhitney test for anti-S. mutans IgA between the young adult groups $(p=0.013)$. Caries-free young 
Koga-Ito CY, Martins CAP, Balducci I, Jorge AOC. Correlation among mutans streptococci counts, dental caries, and IgA to Streptococcus mutans in saliva. Braz Oral Res 2004;18(4):350-5.

adults presented higher IgA level in relation to young adults with caries.

Considering the children groups and OD values obtained for anti-Streptococcus mutans IgA, we can observe that statistically significant differences could be detected among the groups (ANOVA, Kruskal-Wallis, $\mathrm{kw}=12.67 ; \mathrm{df}=2 ; \mathrm{p}=0.001$ ). The multiple comparison test (Dunn's test $5 \%$ ) showed that the OD values obtained for children with rampant caries were higher in relation to the other groups (Graph 1).

Spearman's rank order correlation test indicated no significant correlation between mutans streptococci counts and salivary IgA levels in all the studied groups (caries-free children, $r=0.20$, $\mathrm{p}=0.28$; children with caries, $\mathrm{r}=0.03, \mathrm{p}=0.81$; children with rampant caries, $r=-0.02, p=0.93$;

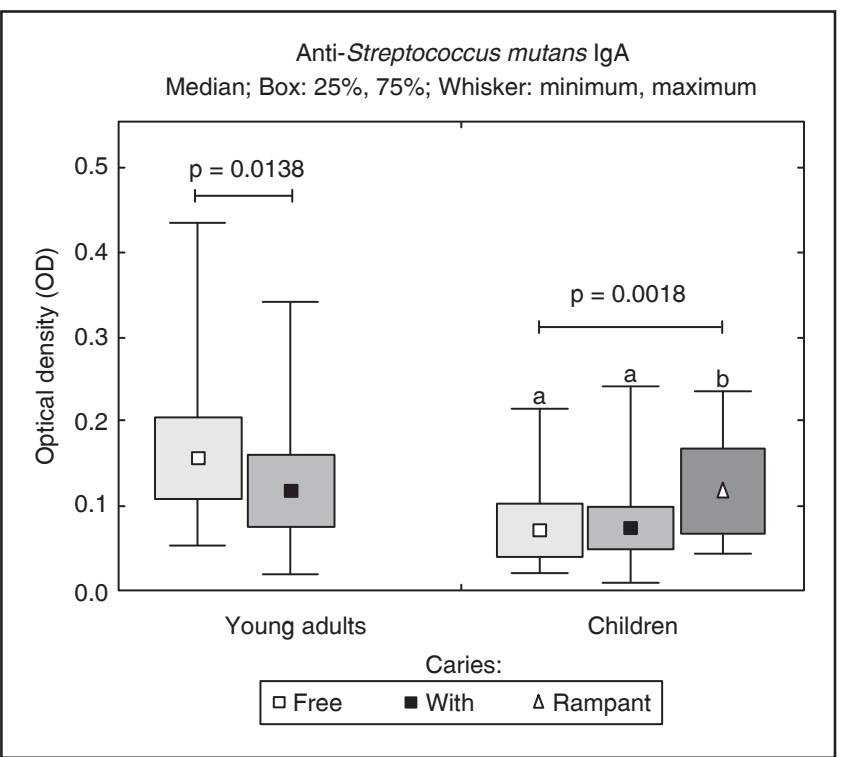

GRAPH 1 - Box plot for optical density (OD) values obtained for anti-Streptococcus mutans IgA and studied groups. Mann-Whitney's test (young adult groups) and Kruskal-Wallis/Dunn's test (children groups) results obtained for the comparison among the groups. Different lowercase letters represent statistical significant difference by Dunn's test. caries-free young adults, $r=0.04, p=0.84$; young adults with caries, $\mathrm{r}=0.02, \mathrm{p}=0.84$ ).

Mutans streptococci were isolated from all the saliva samples examined. The most frequently isolated species was $S$. mutans $(94.53 \%)$. S. sobrinus isolates $(5.47 \%)$ were also found (Table 1$)$.

\section{DISCUSSION}

Similar values of OHI-S were observed between the groups of children with and without caries. The same was observed between the groups of young adults. This result reinforces the multifactorial characteristics of dental caries etiology. Moreover, we must consider the specific plaque hypothesis and the role of cariogenic microorganisms in the dental caries process ${ }^{6}$. According to this hypothesis, the composition of the dental biofilm is more important than its quantity for this disease's etiology. The group of children with rampant caries presented the highest OHI-S. The presence of caries lesions can lead to higher dental plaque retention and also more difficulty in the accomplishment of oral hygiene. In the group of children with rampant caries, mutans streptococci counts were similar in relation to the other groups. Among these patients, it is possible that lactobacilli but not mutans streptococci counts were raised, since these microorganisms are related to the progression of caries lesions ${ }^{1,8}$.

Analyzing the data obtained for salivary flow evaluation we could observe that the mean values obtained are almost identical among the groups of children (caries free $-1.59 \mathrm{ml} / \mathrm{min}$, with caries $1.50 \mathrm{ml} / \mathrm{min}$ and with rampant caries $-1.58 \mathrm{ml}$ / min). This is in accordance with the findings of Tukia-Kulmala, Tenovuo ${ }^{23}$ (1993), who showed a value of $1.56 \mathrm{ml} / \mathrm{min}$. Among the groups of young adults, the mean values were also similar (caries free $-2.03 \mathrm{ml} / \mathrm{min}$ and with caries $-2.09 \mathrm{ml} /$ min).

The levels of IgA in saliva were significantly higher in children with rampant caries in relation

TABLE 1 - Number and percentage of mutans streptococci species isolated from each studied group.

\begin{tabular}{|c|c|c|c|c|c|c|}
\hline \multirow{2}{*}{$\begin{array}{c}\text { Species of } \\
\text { Streptococcus }\end{array}$} & \multicolumn{3}{|c|}{$\begin{array}{c}\text { Children } \\
\text { n (\%) }\end{array}$} & \multicolumn{2}{|c|}{$\begin{array}{c}\text { Young adults } \\
\mathrm{n}(\%) \\
\end{array}$} & \multirow{2}{*}{ Total } \\
\hline & Caries-free & With caries & With rampant caries & Caries-free & With caries & \\
\hline S. mutans & $256(94.1)$ & 104 (92.9) & $97(95.1)$ & 54 (97.7) & 163 (95.9) & $674(94.53)$ \\
\hline S. sobrinus & $8 \quad(2.9)$ & $7 \quad(6.1)$ & - & - & $\begin{array}{ll}5 & (2.9)\end{array}$ & $39 \quad(5.47)$ \\
\hline Total & 272 & 112 & 102 & 57 & 170 & 713 \\
\hline
\end{tabular}


Koga-Ito CY, Martins CAP, Balducci I, Jorge AOC. Correlation among mutans streptococci counts, dental caries, and IgA to Streptococcus mutans in saliva. Braz Oral Res 2004;18(4):350-5.

to the other children groups. Similar results were observed by Naspitz et al. ${ }^{17}$ (1999). On the other hand, these results differ from the observations of Cämling et al. ${ }^{4}$ (1987) and Bolton, Hlava ${ }^{2}$ (1992). These authors related higher IgA anti-Streptococcus mutans antibodies in caries-resistant children in relation to caries-susceptible ones. These results are consistent with the view that children with rampant caries are not immunologically compromised, and that inadequate diet, host and microbiota-related factors may be mainly responsible for their clinical condition.

On the other hand, considering the young adult groups, the highest anti-Streptococcus mutans IgA level was observed among caries-free individuals. The difference of immunological response in children and young adult groups may be related to the age-dependent variations in IgA concentrations as reported by Tappuni, Challacombe ${ }^{21}$ (1995). These authors observed lower concentrations of IgA in children in relation to adults. Our results lead us to question whether the immunological response to $S$. mutans, becoming more effective with age, could reach protective levels at the age of 18-25 years (young adults). If median values of anti-S. mutans levels are compared, the values observed for children with and without caries are similar

\section{REFERENCES}

1. Anderson MH, Bales DJ, Omnell KA. Modern management of dental caries: the cutting edge is not the dental bur. $\mathrm{J}$ Am Dent Assoc 1993;124(6):36-44.

2. Bolton RW, Hlava GL. Evaluation of salivary IgA antibodies to cariogenic microorganisms in children. Correlation with dental caries activity. J Dent Res 1992;61(11):1225-8.

3. Bradford M. A rapid and sensitive method for the quantification of microgram quantities of protein utilizing the principle of protein dye binding. Anal Biochem 1976;72:24854.

4. Cämling E, Ghanberg L, Krasse B. The relationship between IgA antibodies to Streptococcus mutans antigens in human saliva and breast milk and the numbers of indigenous oral Streptococcus mutans. Arch Oral Biol 1987;32(1):21-5.

5. Challacombe SJ, Percival RS, Marsh PD. Age-related changes in immunoglobulin isotypes in whole and parotid saliva and serum in healthy individuals. Oral Microbiol Immunol 1995;10(4):202-7.

6. Emilson CG, Krasse B. Support for and implications of the specific plaque hypothesis. Scand J Dent Res 1985;93(2):96104.

7. Fontana M, Buller TL, Dunipace AJ, Stookey GK, Gregory RL. An in vitro microbial-caries model used to study the efficacy of antibodies to Streptococcus mutans surface proteins in preventing dental caries. Clin Diagn Lab Immunol 2000;7(1):49-54.
(0.07), suggesting no protective effect. On the other hand, the group of caries-free young adults presented higher IgA levels in relation to the group of adults with caries (median values $=0.14$ and 0.11 , respectively).

No correlation could be observed between the counts of mutans streptococci in the saliva and levels of IgA. These results are in accordance with those of Cämling et al. ${ }^{4}$ (1987). These authors stated that IgA to Streptococcus mutans did not reflect the quantity of mutans streptococci at the moment of saliva collection.

\section{CONCLUSION}

Our results suggest that the level of IgA to Streptococcus mutans in saliva did not reflect the salivary mutans streptococci concentrations.

A correlation between increased anti-Streptococcus mutans IgA levels and caries-free status was observed among young adults but not among children. IgA response was eminent when children were really infected by mutans streptococci, resulting in rampant caries. This may suggest a response reflecting the infectious nature of severe dental caries in contrast to the presence of small lesions.

8. Gabris K, Nagy G, Madlena M, Denes Z, Marton S, Keszthelyi $\mathrm{G}$, et al. Associations between microbiological and salivary caries activity tests and caries experience in Hungarian adolescents. Caries Res 1999;33(3):191-5.

9. Greene JC, Vermillion JR. The simplified oral hygiene index. J Am Dent Assoc 1964;68:25.

10. Gregory RL, Kindle JC, Hobbs LC, Filler SJ, Malmstrom HS. Function of anti-Streptococcus mutans antibodies: inhibition of virulence factors and enzyme neutralization. Oral Microbiol Immunol 1990;5:181-8.

11. Hardie JM. Genus Streptococcus. In: Bergey's manual of systematic bacteriology. Baltimore: Williams \& Wilkins; 1986.

12. Kennedy AE, Shklair IL, Hayashi JA, Bahn AN. Antibodies to cariogenic streptococci in humans. Arch Oral Biol 1968;13(10):1275-8.

13. Krasse B. Interpretation and use of microbiologic findings in dental caries. Oral Microbiol Immunol 1986;1:856.

14. Krasse B, Gahnberg L. Available immunoglobulin A antibodies in mouth rinses and implantation of Streptococcus mutans. Infect Immun 1983;41(3):1360-2.

15. Legler DW, McGhee JR, Lynch DP, Mesteck JF, Shaefer ME, Carson J, et al. Immunodeficiency disease and dental caries in man. Arch Oral Biol 1981;26(11):905-10. 
Koga-Ito CY, Martins CAP, Balducci I, Jorge AOC. Correlation among mutans streptococci counts, dental caries, and IgA to Streptococcus mutans in saliva. Braz Oral Res 2004;18(4):350-5.

16. Närhi TO, Tenovuo J, Ainamo A, Vilja P. Antimicrobial factors, sialic acid, and protein concentration in whole saliva of the elderly. Scand J Dent Res 1994;102(2):120-5.

17. Naspitz GM, Nagao AT, Mayer MP, Carneiro-Sampaio MM. Anti-Streptococcus mutans antibodies in saliva of children with different degrees of dental caries. Pediatr Allergy Immunol 1999;10(2):143-8.

18. Olsson J, Svanberg M. Oral implantation in man of Streptococcus mutans in relation to salivary IgA activity. Scand J Dent Res 1991;99(6):489-97.

19. Orstavik D, Brandzaeg P. Secretion of parotid IgA in relation to gingival inflammation and dental caries experience in man. Arch Oral Biol 1975;20(11):701-4.

20. Russell MW, Hajishengallis G, Childers NK, Michalek SM. Secretory immunity in defense against cariogenic mutans streptococci. Caries Res 1999;33(1):4-15.
21. Tappuni AR, Challacombe SJ. A comparison of salivary immunoglobulin A (IgA) and IgA subclass concentrations in predentate and dentate children and adults. Oral Microbiol Immunol 1995;9(3):142-5.

22. Tenovuo J, Jentsch H, Soukka T, Karhuvaara L. Antimicrobial factors of saliva in relation to dental caries and salivary levels of mutans streptococci. J Biol Buccale 1992;20(2):85-90.

23. Tukia-Kulmala $\mathrm{H}$, Tenovuo J. Intra- and inter-individual variation in salivary flow rate, buffer effect, lactobacilli, and mutans streptococci among 11- to 12-year-old schoolchildren. Acta Odontol Scand 1993;51(1):31-7.

24. World Health Organization. Basic oral health survey methods. Geneva: World Health Organization; 1977.

Received for publication on Jun 14, 2004

Sent for alterations on Aug 16, 2004 Accepted for publication on Sep 14, 2004 